\title{
The Relationship between Workload and Nursing Job Satisfaction in One Private Hospital in The West Region of Indonesia
}

\author{
Gita Martinaningtyas ${ }^{\mathrm{a}}$, Lenceria Girsang ${ }^{\mathrm{a}}$, Widia Astuti ${ }^{\mathrm{a}}$, Martina Pakpahan. ${ }^{\mathrm{a}}$, Dora Irene \\ Purimahua $^{\mathrm{a}}$ \\ ${ }^{a}$ Faculty of Nursing, Universitas Pelita Harapan, Karawaci, Tangerang \\ e-mail : dora.purimahua@uph.edu
}

\begin{abstract}
Nurse as a profession and caregiver who composed the large portion of healthcare service workers is required to have high expertise in carrying out nursing practice, the speed at work, and high work volume. With these important roles, the income earned by nurses is still in the low category as a healthcare provider that makes nurses feel dissatisfied in their work. The purpose of this study was to describe the workload of nurses, level of work satisfaction and to find out the relationship between the workloads in nursing and the job satisfaction in one private hospital in the west region of Indonesia. This study used a quantitative method with a cross-sectional approach. Data were collected using a questionnaire of nursing workload and nursing job satisfaction on 126 nurses in one private hospital in the west region of Indonesia with a total sampling technique. Univariate and bivariate were conducted to analyze the collected data. This study found that there were $55 \%$ of nurses with high workload and 52\% of nurses with job dissatisfaction. There was a relationship between workloads to nursing job satisfaction (p-value 0.001). This research recommend the hospitals to reevaluate nurses job satisfaction, give reward and set excellent and evident career path in nursing.
\end{abstract}

Keywords: Nurse, Hospitals, Workload, Job Satisfaction. 


\section{Introduction}

Hospitals as the healthcare provider have to have a good quality standard to care for the patient and the other healthcare user. In the way to increase the quality of healthcare services of hospitals, the one aspect that needed to increase is the quality and the performance of the nurses. The nurse is a profession that has a large portion of healthcare services and directly interacted with the patient. According to a research by Nainggolan (2010), (40-60\%) healthcare services in the hospitals was provided by nurses. This condition should get big attention in operational of a Hospital to deliver healthcare services. The quality of healthcare services provided by nurses can be the indicators to ensure the quality either good or bad of a hospital.

World Health Organization explained that Indonesia is one of six countries in South Asia and Southeast Asia that has a lack of trained health workers, either the Physicians, the Nurses or the Midwives (WHO, 2012). Nurses as the largest number of health workers in Indonesia as 147.264 nurses with ratio 87,67 per 100.000 population in Indonesia and the total number of Indonesians in 2015 are 255.461.686. This is still far from the 2019 target of 180 per 100.000 population (Kemenkes, 2017). These data shown that the ratio of healthcare workers and the community is still far from the target.

Workloads of nurses are all of the activities that nurses do while on duty in a nursing service unit (Marquis and Huston, 2010). Sunyoto (2012) said that workloads of nurses are required to have high expertise in carrying out nursing practice, the speed at work, and high work volume. Related to workload, there was a survey by can be the indicators of the good or bad quality of healthcare services. Based on a survey by Indonesian National Nurses Association (20009) in Makassar found that there were 51\% nurses got stress in work, weakness and lack of rest due to high workload while the nurse got low income without inadequate incentive so they had low job satisfaction and burnout occurred.

Research by Runtu et al. (2018) found that $(56 \%)$ nurses have severe workload. This is because a lot of work that exceeds capacity so it can cause the physical condition of nurses will be easily tired and easily tense. A lot of workloads, meet of needs, and cure the problems will take a lot of energy by physical and psychological of the nurses.

Job satisfaction is a form of someone's perception that reflected in the attitude and has a focus on behavior towards work (Robin, 2008). In assessing job satisfaction of the nurses, there are some concern aspects which is seen from the nurse's characteristic and several workloads that nurses took. Sutarni (2008) in 
her research shown that nurses have (54\%) dissatisfaction in work. Then she also explained that the length of working is also influence job satisfaction. Nurses with the longest time of working have more experience in achievement, award, responsibility, skillful, and completeness of working. The purpose of the study was to identify the relationship between nursing workload and job satisfaction in one private hospital in the west region of Indonesia.

\section{Method}

This study used a quantitative correlational method with the crosssectional approach which is nonexperimental research to find out the dynamic of correlation between risk factors and the effect, with observation approach or collecting data in one time (Noto atmodjo, 2010).

This study conducted in one private hospital in the west region of Indonesia, in all the inpatient room, outpatient room, emergency department, operating room, intensive care unit, and chemotherapy room from June-July of 2019. With total sampling techniques, 126 nurses were involved in this study as the respondent. This study used questionnaire as the instrument developed by three related research.

Tahsina (2013) with her study about the factors that related to job satisfaction in Rumah Sehat Terpadu Hospitals in Parung, Bogor. Arifin (2017) in his study about the relationship between workload and nursing job satisfaction in emergency department in Jombang Hospitals and Sutarni (2008) with her study about the relationship between workload and nursing job satisfaction in inpatient room of Dharmais Cancer Hospitals. Then, the three questionnaires were evaluated for validity and reliability. The questionnaire was valid in 14 questions about workload $(r=0.386$ to 0.878 ) and 20 question about job satisfaction ( $r=0.377$ to 0.865 ). This questionnaire was reliable to use by Cronbach- $\alpha$ for workload was 0.891 , and job satisfaction was 0.895 .

The collected data were transferred to the software program of statistic then analyzed in univariate and bivariate. This study used the chi-square test to bivariate analyzes. This study has passed ethical study where the researcher held an ethical principle such as inform concern, anonymity, and confidentiality.

\section{Result}

Univariate Analyze

Table 1. Respondents' Characteristics $(n=126)$

\begin{tabular}{lll}
\hline $\begin{array}{l}\text { Respondent } \\
\text { Characteristic }\end{array}$ & f & $\%$ \\
\hline Sex & & \\
\hline Male & 28 & 22. \\
\hline Female & 98 & 77.8 \\
\hline Age & & \\
\hline $20-30$ years old & 113 & 89.7 \\
\hline $31-40$ years old & 11 & 8.73 \\
\hline$>41$ years old & 2 & 1.57 \\
\hline Level of education & & \\
\hline Vocational in Nursing & 1 & 0.8 \\
\hline Diploma in Nursing & 29 & 23.01 \\
\hline Bachelor in Nursing & 21 & 16.67 \\
\hline Professional in Nursing & 75 & 59.52 \\
\hline Length of work & & \\
\hline
\end{tabular}


NERS: Jurnal Keperawatan, Volume 16, No. 2, Oktober 2020, (Hal. 95-102)

\begin{tabular}{lll}
\hline experience & & \\
\hline$<1$ year & 45 & 35.71 \\
\hline $1-3$ years & 35 & 27.78 \\
\hline 4-5 years & 27 & 21.43 \\
\hline$>5$ years & 19 & 15.08 \\
\hline
\end{tabular}

Table 1 shown that the majority of the respondents were: female were $77.8 \%(n=98)$, in range of age $20-30$ years old were $89.7 \%$ $(\mathrm{n}=113)$, professional nurse were $59.52 \%(n=75)$, and length of working were $<1$ year $35.71 \%(n=45)$.

Table 2. Distribution of Respondents by Workload $(n=126)$

\begin{tabular}{ll}
\hline Nursing Workload & $\mathbf{N}(\%)$ \\
\hline Mild & $57(45 \%)$ \\
\hline Severe & $\underline{69(55 \%)}$ \\
\cline { 1 - 1 } Total & $\underline{126(100 \%)}$ \\
\hline
\end{tabular}

Table 2 shown that nurses in the hospitals had severe workload were $55 \%(n=69)$, while nurses with mild workload were $45 \%$ $(n=57)$.

Table 3. Distribution of Respondets by Job Satisfaction $(n=126)$

\begin{tabular}{ll}
\hline Job Satisfaction & n (\%) \\
\hline Dissatisfaction & $65(52 \%)$ \\
\hline Satisfaction & $61(48 \%)$ \\
\hline Total & $126(100 \%)$ \\
\hline
\end{tabular}

Table 3 shown that nurses with dissatisfaction were $52 \%(\mathrm{n}=65)$, while nurses with satisfaction were $48 \%(n=61)$.

\section{Bivariate Analyzes}

Table 4. Distribution of The Relationship between Workload and Job Satisfaction $(n=126)$

\begin{tabular}{|c|c|c|c|c|c|c|c|}
\hline \multirow{3}{*}{$\begin{array}{l}\text { Job } \\
\text { Satisfaction } \\
\end{array}$} & \multicolumn{6}{|c|}{ Workload } & \multirow{2}{*}{$\begin{array}{l}\rho \text { - } \\
\text { value }\end{array}$} \\
\hline & $\overline{\text { Mild }}$ & & Severe & & Total & & \\
\hline & $\mathrm{n}$ & $\%$ & $\mathrm{n}$ & $\%$ & $\mathrm{n}$ & $\%$ & \\
\hline Dissatisfaction & 20 & 16 & 45 & 36 & 65 & 52 & \\
\hline Satisfaction & 37 & 29 & 24 & 19 & 61 & 48 & \\
\hline Total & 57 & 45 & 69 & 55 & 126 & 100 & 0,001 \\
\hline
\end{tabular}

Bivariate analyze used the chisquare test to find out the relationship between workload and job satisfaction. Table 4 shown that $\rho$-value was 0.001 .

\section{Discussion \\ Workload}

Table 2 shown that nurses in the hospitals had severe workload were $55 \% \quad(n=69)$. Hart and Staveland by Tarwaka said that three main factors formed workload such as demands of duty, efforts, and performances (Tarwaka, 2015). The result of this study related with an observation by researchers in one private hospital in the west region of Indonesia which the nurses state that pressure by time, cognitive load, emotional burden involved to workload and the level of turnover. This study also related to a study by Mike in 2011 which found that nurses in inpatient room were in the severe level of workload $(52.2 \%)$. Saputra in his study also mentions the same thing that the nurses who worked in the inpatient room have a severe level of workload $(55,6 \%)$. However, the nursing workload can not be defined clearly 
because of the load of work from one another is different. Sometimes, nurses with a lot of tasks feel fine with their workload while the other with the same quantity feels that as a heavy burden. The portion of the workload needs to be clearly defined based on the skill, and competence and even based on the characteristic of the nurses. Equality needs to appear.

\section{Job Satisfaction}

Table 3 shown that nurses with dissatisfaction were $52 \%(\mathrm{n}=65)$. This result was similar with a study by Gatot and Adisasmito that the nurses in the inpatient room have dissatisfaction with their work as $62.9 \%$ (Saputra, 2016). The study by Yanidrawati (2012) also found that nurses have a very high level of dissatisfaction as $92.96 \%$. This result also in line with some interview by a researcher withsome nurses in one private hospital in the west region of Indonesia. The nurses stated that they feel dissatisfy due to their low income, the promotion to increase their position in their career, and also dissatisfied with the co-worker. Related to this, Nursalam explained three factors affect job satisfaction including motivation, work environment, and the roles of the leaders (Nursalam, 2009). On the other hand, this study found that co- workers, income, and job promotion had a big influence on the satisfaction of the nurses. These three components need to be further identified individually.

\section{The Relationship between Workload and Nursing Job Satisfaction}

According to the result of the chi-square test that used to analyze the relationship between workload and nursing job satisfaction, nurses with the mild workload and satisfy with their work as $29 \%$, while mild workload and dissatisfy as $16 \%$. This result has shown that nurses with mild workloads tend to feel satisfied at work. In contra, nurses with a severe level of workload and satisfy as $19 \%$, while nurses with a severe level of workload and dissatisfy as $36 \%$. Severe workload and dissatisfaction in work need to attend. This result was similar to a study from Sutarni with a descriptive correlational design to 77 nurses found that the workload of the nurse was at a severe level as $62.3 \%$, and has job dissatisfaction as $54,5 \%$. The other study by Barahama and friends in 2019 also found a huge amount of workload at a sever level as $67.2 \%$ and dissatisfaction with their job as $51.7 \%$ [19].

The chi-square test that used to identify the relationship 
between workload and job satisfaction deliver the $\rho$-value as 0.001 , which means that there was a relationship between these two things. Seen from the percentage in Table 4, Nurses who dissatisfy with their workload as $52 \%$, while nurses who satisfy with their workload as $48 \%$. This difference is only slightly compared to the phenome previously revealed by the researchers. However, the hypothesis that there was a relationship between workload and nursing job satisfaction is accepted. This study did not identify the other factors that might influence either workload or job satisfaction of the nurses. The next researcher is recommended to identify those factor that might be related with workload and job satisfaction such as stress, the environment, motivation, etc. so that will be more relevant to see the relationship between workload and nursing job satisfaction.

\section{Limitation}

The study did not identify nurse's workloads by their length of work experience and level of education.

\section{Conclusion}

Based on the results of the study it can be concluded:

The workload of nurses majority were in severe as $55 \%$. The job satisfaction of nurses majority were in dissatisfaction as $52 \%$. There was a relationship between workload and nursing job satisfaction in one private hospital in Indonesia ( $\rho$-value $=$ 0.001)

This research recommend the hospitals to re-evaluate nurses job satisfaction, give reward and set excellent and evident career path in nursing. This research recommend the future researchers to identify and compare nursing workloads and job satisfaction based on the level of nurse education mentioned in the Nursing Act in Indonesia that conventional nurses and professional nurses have different roles and responsibilities. Job satisfaction will be better identified by mixed methods.

\section{References}

Arifin, C. (2017) Hubungan Beban Kerja dengan Kepuasan Kerja Perawat Instalasi Gawat Darurat (IGD) (Studi Korelasi di RSUD Jombang). Sekolah Tinggi Ilmu Kesehatan Insan Cendekia Medika, Jombang. Retrivied

from:http://repo.stikesicmejbg.ac.id/ 54/3/SKRIPSI_CHOIRUL_ARIFIN $\% 28133210012 \% 29$.pdf.

Barahama, K.F., Katuuk, M., Oroh, W.M.: Hubungan Beban Kerja Dengan Kepuasan Kerja Perawat Di Ruangan Perawatan Dewasa Rsu Gmim Pancaran Kasih Manado. Jurnal Keperawatan 7(1). Universitas Sam Ratulangi, Manado. (2019) 
Kementerian Kesehatan RI (2017): Pusat Data dan Informasi. Jakarta Selatan. Retrivied from: www.depkes.go.id/download.php?fil e=download/pusdatin/lain-lain/.

Marquis, B. L., Huston, C.J. (2010): Kepemimpinan dan Manajemen Keperawatan: Teori dan Aplikasi (Ed. 4). EGC, Jakarta.

Mike, M. (2011) Hubungan Beban Kerja Perawat dengan Produktivitas Kerja Perawat di IRNA Non Bedah (Penyakit Dalam) RSUP. DR. M. Djamil Padang. Universitas Andalas, Padang. Retrivied from: http://repo.unand.ac.id/217/.

Nainggolan, M.J. 2010 : Pengaruh Supervisi Kepala Ruangan terhadap Kinerja Perawat Pelaksana di Rumah Sakit Islam Malahayati Medan (Skripsi). Universitas Sumatra Utara, Medan.World Health Organization (WHO). (2012). Retrivid from Ruang Berita: http://www.pdpersi.co.id/conten t/news.php? $\mathrm{mid}=5 \&$ nid $=915 \& \mathrm{c}$ $\underline{\text { atid }=23 .}$.

Notoatmodjo, S.: Metodologi Penelitian Kesehatan. Rineka Cipta, Jakarta. (2010)

Nursalam: Manajemen Keperawatan dan Aplikasinya. Penerbit Salemba Medika, Jakarta. (2009)

PPNI (2009): Hubungan Tuntutan Tugas, Tuntutan Peran, dan Tuntutan
Antarpribadi dengan Stress Kerja Pada Perawat di Bagian IGD Rumah Sakit Haji Kota Makassar. Universitas Islam Negeri Alauddin, Makassar.

Runtu, V., Pondaag, L., \& Hamel, R. (2018). Hubungan Beban Kerja Fisik dengan Stres Kerja Perawat di Ruang Instalasi Rawat Inap Rumah Sakit Umum GMIM Pancaran Kasih Manado. Program Studi Ilmu Keperawatan Fakultas Kedokteran Universitas Sam Ratulangi, Manado. Retrivied from: https://ejournal.unsrat.ac.id/index.ph p/jkp/article/view/19475/19026.

Robbins. (2008). BAB II Tinjauan Pustaka. Universitas Negeri, Lampung. Retrivied from:http://digilib.unila.ac.id/9487/1 4/BAB\%20II.pdf.

Sunyoto. (2012): Pengaruh Beban Kerja Terhadap Stres Kerja dan Dampaknya Terhadap Kinerja Karyawan, Universitas Negeri Surabaya, Surabaya.

Sutarni, N. (2008). Hubungan Beban Kerja dengan Kepuasan Kerja Perawat Pelaksana di Instalasi Rawat Inap Rumah Sakit Kanker Dharmais, Jakarta.

Tahsina, N (2013). Faktor-Faktor yang Berhubungan dengan Kepuasan Kerja Perawat di RS. Rumah Sehat Terpadu Parung, BogorFakultas 
NERS: Jurnal Keperawatan, Volume 16, No. 2, Oktober 2020, (Hal. 95-102)

Kedokteran dan Ilmu Kesehatan Universitas Islam Negeri Syarif Hidayatullah, Jakarta. Retrivied from:

http://repository.uinjkt.ac.id/dspace/b itstream/123456789/25901/1/Nadia \%20Tahsinia- fkik.pdf.

Tarwaka. (2015) Ergonomi Industri Dasar-Dasar Pengetahuan Ergonomi dan Aplikasi di Tempat Kerja. Harapan Press, Surakarta.

Saputra, T. R. 2016. Hubungan Beban Kerja Perawat dengan Mutu Pelayanan Keperawatam di Rawat Inap Rumah Sakit Umum Daerah Sultan Syarif Mohamad Alkadrie Kota Pontianak Tahun 2016. Jurnal Proners Vol 3(1), Pontianak. Retrivied from: http://jurnal.untan.ac.id/index.php/jm keperawatanFK/article/view/21139.

Yanidrawati, K. (2012) Hubungan Kepuasan Kerja dengan Kinerja Perawat di Ruang Rawat Inap Rumah Sakit Umum Daerah Kabupaten Bekasi.Retrivied from:http://journal.unpad.ac.id/ejou rnal/article/view/753. 